\title{
Risk Factors for Systemic Reduced Bone Mineral Density in Premenopausal Female Patients with Early Untreated Rheumatoid Arthritis
}

\author{
Risikofaktoren für eine systemische Reduktion der Knochendichte \\ bei prämenopausalen Patientinnen mit nicht vorbehandelter \\ früher rheumatoider Arthritis
}

Authors

Hamada S. Ahmed ${ }^{1}$, Sherif E. Farrag ${ }^{1}$, Amr E. Okasha ${ }^{1}$, Gamal Othman ${ }^{2}$, Ibrahim Shady ${ }^{3}$

Affiliations

1 Mansoura University Faculty of Medicine, Rheumatology and Reahb. Dep, Mansoura, Egypt

2 Mansoura University Faculty of Medicine, Biochemistry Dep., Mansoura, Egypt

3 Mansoura University Faculty of Medicine, Public Health and community medicine, Mansoura, Egypt

Schlüsselwörter

Frühe rheumatoide Arthritis, Osteoporose, Rheumafaktor, Antikörper gegen citrullinierte Proteine

Key words

Early rheumatoid arthritis, osteoporosis, anti-citrullinated protein antibodies, rheumatoid factor

Bibliography

DOI https://doi.org/10.1055/a-0591-2364

Published online: 18.4 .2018

Akt Rheumatol 2020; 45: 334-340

(c) Georg Thieme Verlag KG Stuttgart · New York

ISSN 0341-051X

Correspondence

Ibrahim Shady

Medical Doctorate of Public Health, Preventive med

Mansoura University Faculty of Medicine

Public Health and community medicine

Mansoura University

35516 Mansoura

Egypt

Tel.: + 96550809 023, Fax: + 96524913486

ebrshady@hotmail.com

\section{ABSTRACT}

Background Systemic osteoporosis (OP) is evident among patients with early rheumatoid arthritis (ERA). This study aimed to investigate the OP risk factors in patients with ERA and who was treatment-naïve at inclusion.
Subjects and Methods Systemic bone mineral density (BMD) of the lumbar spine (LS), femoral neck (FN) and total hip (TH) was measured in 135 treatment-naïve premenopausal females with early Rheumatoid Arthritis (ERA). For all patients, demographic data, vitamin D status, and the specific parameters of the disease, including disease activity, serum levels of rheumatoid factor and anti-citrullinated protein antibodies (ACPA) were evaluated.

Results T score was $<-1.0$ in the LS in $16.2 \%$, in the FN in $22.2 \%$ and in the $\mathrm{TH}$ in $23.7 \%$. Among our patients, $29.6 \%$ had below normal T score at any site. Demographic characteristics, RA duration, diseases activity did not significantly impact BMD. However, patients with decreased BMD were more prevalent ACPA- and rheumatoid factor (RF)-positive than patients with normal BMD. Also, high titer ACPA or RF is associated with more marked reduction in BMD. In regression analysis, after adjustment for possible confounders, patient stratification according to ACPA status and RF status (into negative, low-positive and high positive) still a significant independent variable associated with lower BMD values.

Conclusion Presence of ACPA or RF is associated with increased risk for development of reduced systemic BMD from very early stage of rheumatoid arthritis. Furthermore, this risk increases more with higher levels of ACPA or RF. Measurement of BMD should be performed for ACPA- or RF-positive patients with early RA.

\section{ZUSAMMENFASSUNG}

Hintergrund Die systemische Osteoporose (OP) tritt vermehrt bei Patientinnen mit früher rheumatoider Arthritis (ERA) auf. Ziel dieser Studie war die Abschätzung des OP-Risikos bei Patientinnen mit ERA, die bei Studieneinschluss nicht vorbehandelt waren.

Probanden und Methoden Bei 135 nicht vorbehandelten prämenopausalen Frauen mit früher rheumatoider Arthritis (ERA) wurde die systemische Knochendichte (BMD) der Lendenwirbelsäule (LS), des Oberschenkelhalses (FN) und der Gesamthüfte (TH) gemessen. Bei allen Patientinnen erfolgte eine 
Beurteilung demografischer Daten, des Vitamin-D-Status und der spezifischen Parameter der Erkrankung einschließlich Krankheitsaktivität sowie Serumspiegel des Rheumafaktors und der Antikörper gegen citrullinierte Proteine (ACPA).

Ergebnisse Ein T-Score von $<-1,0$ wurde in der LS bei 16,2\%, im FN bei 22,2\% und in der TH bei 23,7\% der Patientinnen gemessen. Von unseren Patientinnen wiesen $29,6 \%$ in irgendeinem Körperareal einen T-Score unterhalb des Normbereichs auf. Demografische Merkmale, Dauer der RA und Krankheitsaktivität wirkten sich nicht signifikant auf die BMD aus. Bei Patientinnen mit verminderter Knochendichte wurden jedoch häufiger ACPA und Rheumafaktoren (RF) nachgewiesen als bei Patientinnen mit regelrechter Knochendichte. Außerdem ist ein hoher ACPA- oder RF-Titer mit einer stärker ausgeprägten Reduktion der BMD assoziiert. In der Regressionsanalyse, durchgeführt nach Bereinigung um mögliche Störfaktoren, stellt die Stratifizierung der Patientinnen nach ACPA- und RF-Status (in negativ, schwach positiv und stark positiv) nach wie vor eine signifikante unabhängige Variable dar, die mit niedrigeren BMD-Werten assoziiert ist.

Schlussfolgerung Das Vorliegen von ACPA oder RF bei Patientinnen mit rheumatoider Arthritis in einem sehr frühen Stadium ist mit einem erhöhten Risiko einer reduzierten systemischen BMD assoziiert. Dieses Risiko nimmt mit steigendem ACPAoder RF-Spiegel weiter zu. Bei ACPA- oder RF-positiven Patientinnen mit früher RA sollte eine Messung der BMD erfolgen.

\section{Introduction}

Osteoporosis and its clinical consequence fracture is a well-known extra-articular manifestation in rheumatoid arthritis (RA) [1]. Osteoporosis prevalence among RA patients is approximately double that found in general population [2]. The overall occurrence of systemic osteoporosis in RA patients ranges from 12.3 to $38.9 \%$ at the site of lumbar spine (LS) and 6.3 to $36.3 \%$ at the hip site [2-4]. There is at least a 2-fold to 6-fold increase in vertebral fracture (VF) risk in RA patients than in those with primary osteoporosis $[4,5]$. Moreover, among patients with early RA, up to $10 \%$ had an evidence of systemic bone loss [6]. In addition, VFs were reported in the first year after the onset of RA and around one-third of the females with RA report VF during five years of follow up [7].

It had been long assumed that the increased prevalence of osteoporosis in RA patients is mainly attributed to an inherent RA factors such as chronic inflammatory process in long-standing disease, use of glucocorticoids or some disease-modifying anti-rheumatic drugs (DMARDs), and immobilization. However, these factors do not explain the higher prevalence bone loss and VFs in patients with early RA particularly in treatment naïve patients. In contrary, emerging data suggest that destruction of bone in RA is mainly attributed to: inflammatory and autoimmunity mechanisms $[8,9]$.

Pro-inflammatory cytokines are considered the key drivers of bone tissue destruction by increasing the number of mature osteoclasts $[8,10,11]$. However, autoantibodies in RA patients, especially anti-citrullinated protein antibodies (ACPA), increases the risk of osteoporosis by inducing osteoclast differentiation which increases bone resorption $[12,13]$. It had been reported that ACPA-positive RA patients had increased serum receptor activator of nuclear factor kappa B ligand (RANKL) and had higher rates of joint damage progression over time independent pro-inflammatory cytokines $[14,15]$. In this regard, the clinical features of RA were found to be preceded by ACPA by about $5-10$ years $[9,16]$. Therefore, it is expected that ACPA-positive early RA patients may have signs of generalized bone loss besides joint destruction.

Thus, this study aimed to investigate the risk factors for osteoporosis in patients with early RA and who was treatment-naïve at inclusion.

\section{Methods}

\section{Patients}

In this study, 200 consecutive patients with early inflammatory arthritis were invited to participate in the study. Patients were collected from the outpatient Clinic of Rheumatology and Rehabilitation Department, from different Hospitals in Saudi Arabia during the period from February 2015 till May 2017. All patients were naïve to glucocorticoids and DMARDs, and had short duration of arthritis symptoms ( $\leq 12$ weeks).

Twenty-two patients did not provide a written consent and were excluded from the study. Hence, at inclusion, collection of clinical data, laboratory investigations and BMD measurement were performed only for patients who had provided a written informed consent $(n=178)$. Those patients were followed up. Only data of patients who fulfilled the American College of Rheumatology (ACR)/ European League Against Rheumatism (EULAR) 2010 classification criteria for RA [17] were analyzed $(n=135)$ while patients with diagnoses other than RA ( $n=25)$ or underwent spontaneous remission $(n=18)$ were excluded from the study ( $\boldsymbol{F}$ Fig. 1$)$. This study was approved by the local ethical committees.

\section{Demographic and Clinical Data}

During history taking, data known to affect BMD were obtained including age, gender, body mass index (BMI), menopausal status, current smoking status, risk factors for secondary osteoporosis other than RA, history of osteoporotic fractures, use of calcium and vitamin D supplements, hormone replacement therapy and bisphosphonates. RA duration was defined as the duration since first self-reported joint symptoms was obtained.

\section{Laboratory Investigations}

ACPA \& IgM rheumatoid factor (RF) were measured by a second-generation Phadia Immuno-CAP 250 EliA CCP assay (Phadia, Freiburg, Germany) and by immuno-nephelometry using a Dimension Vista 1500 system (Siemens, Erlangen, Germany) respectively, according to the manufacturers' guidelines. Positive results were considered with values above $10 \mathrm{lU} / \mathrm{mL}$ for ACPA and above $20 \mathrm{IU} /$ $\mathrm{mL}$ for RF. A low antibody level was defined as values greater than 


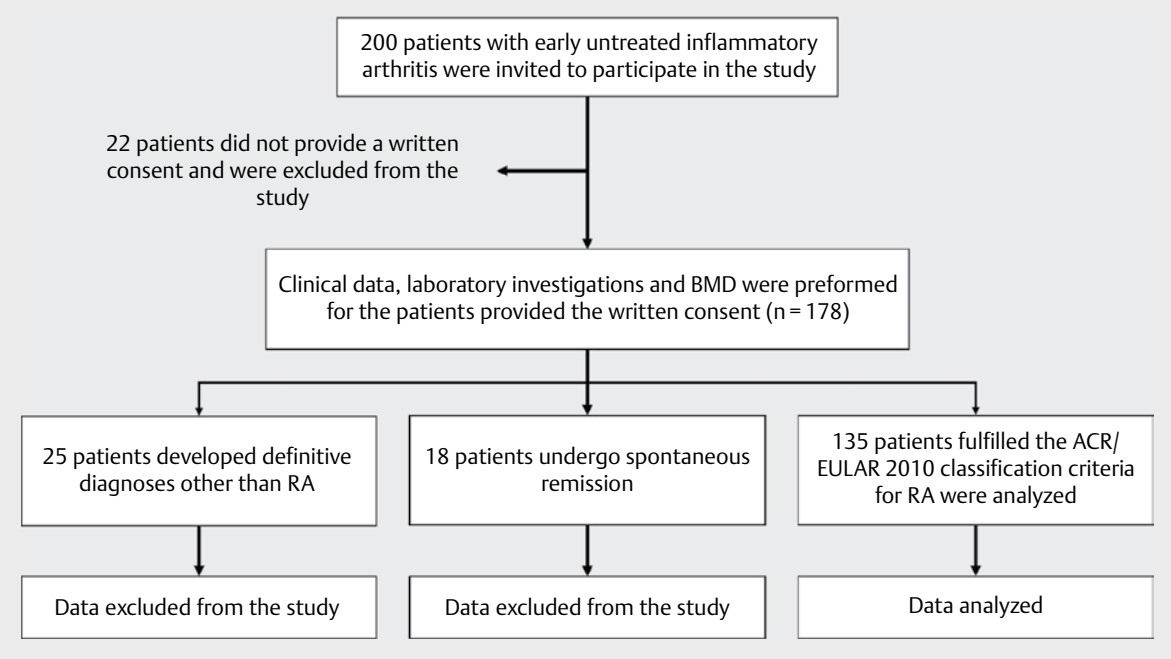

- Fig. 1 Flowchart for identification of population with early rheumatoid arthritis.

the defined upper limit of normal and $\leq 100 \mathrm{IU} / \mathrm{ml}$, and a high antibody level as a value $>100 \mathrm{lU} / \mathrm{ml}$ [18].

Disease activity was assessed using erythrocyte sedimentation rate (ESR) and C-reactive protein (CRP). Disease Activity Score 28 using erythrocyte sedimentation rate (DAS28-ESR) was used to assess RA activity for patient's global assessment (0-100) combining the visual analogue scale, number of tender and swollen joints and ESR [19].

\section{BMD Measurements}

BMD measurements were performed using dual-energy $X$-ray absorptiometry (DXA) equipment (Hologic, Vilvoorde, Belgium) at LS, femoral neck (FN) and total hip (TH). All procedures were performed by a trained technician in accordance with the manufacturers' standardized scan and positioning protocols. Specifically, in the current study we measured BMD from L2 to L4 (LS.BMD), TH (TH.BMD) and FN (FN.BMD). BMD is expressed in $\mathrm{g} / \mathrm{cm}^{2}$. Diagnoses of decreased BMD were made when T-score is $<-1.0$, according to the World Health Organization (WHO) [20]. Besides, osteoporosis is diagnosed on the basis of the lowest T-score at the three sites (LS, FN, and TH) according to recommendations of the International Society for Clinical Densitometry [20].

\section{Statistical Analysis}

All continuous data were tested for normality of distribution prior to any calculations. Continuous data with normal distribution were described as mean and standard deviation (SD) while continuous data not normally distribution was described as median and interquartile range (IQR). Categorical data were described as counts and percent. Comparison of the patient characteristic between patients with reduced BMD and patients with normal BMD were evaluated using the independent samples t test. Possible confounders that are known to impact the BMD (including age, BMI and vitamin D status and duration of the symptoms) were analyzed by regression analyses to evaluate the relationship between the auto-antibodies and the reduced BMD. Statistical analyses were performed using SPSS version 20.0, and $<0.05$ was considered significant.

\section{Results}

\section{Characteristics of the Patients}

- Table 1 demonstrates the characteristics of the 135 patients with early RA enrolled in the study. All patients fulfilled the ACR/ EULAR 2010 classification criteria for RA. The study population was all premenopausal females with an average age of $46.3 \pm 3.6$ years. Patients were treatment-naïve either to glucocorticoids or to DMARDs. The duration of RA ranged from 7-12 weeks with an average of $9.6 \pm 1.7$ weeks. All patients had an active disease with an average DAS28-ESR and -CRP of $4.2 \pm 0.8$ and $3.5 \pm 0.7$ respectively. Of these patients, $54.8 \%$ were RF-positive, $31.9 \%$ were ACPA-positive for and ACPA and $24.4 \%$ were double-positive.

\section{Prevalence of Decreased BMD}

The average BMD at the LS, FN and the TH were $0.927 \pm 0.205$, $0.782 \pm 0.183$ and $0.766 \pm 0.178 \mathrm{gm} / \mathrm{cm}^{2}$ respectively. T score was $<-1.0$ in the LS in $16.2 \%$, in the $\mathrm{FN}$ in $22.2 \%$ and in the $\mathrm{TH}$ in $23.7 \%$. Among our patients, $29.6 \%$ had below normal T score at any site ( $\triangleright$ Table 1$)$.

\section{Relationship of the Decreased BMD with the Demographic Data and Vitamin D}

The age and BMI of the patients were not significantly associated with the decreased BMD as shown in > Table 2. Similarly, the vitamin D status did not differ significantly between the patients with decreased BMD compared to patients with normal BMD ( $\triangleright$ Table 2).

\section{BMD in Relation to Duration of early RA and Activity}

Early RA duration, ESR level, CRP level, DAS28-ESR and DAS28-CRP did not differ significantly between the patients with decreased BMD compared to patients with normal BMD ( 
- Table 1 Demographic and clinical characteristics of the patients with ERA.

\begin{tabular}{|c|c|}
\hline Age (years), mean $\pm S D$ & $46.3 \pm 3.6$ \\
\hline $\mathrm{BMI}\left(\mathrm{kg} / \mathrm{m}^{2}\right)$, mean $\pm \mathrm{SD}$ & $24.2 \pm 3.0$ \\
\hline \multicolumn{2}{|l|}{ Vitamin D status, $\mathrm{n}(\%)$} \\
\hline Normal & $40(29.6)$ \\
\hline Insufficiency & $41(30.4)$ \\
\hline Deficiency & $54(40)$ \\
\hline Duration of RA symptoms (weeks), mean $\pm S D$ & $9.6 \pm 1.7$ \\
\hline DAS28-ESR, mean $\pm S D$ & $4.2 \pm 0.8$ \\
\hline $\mathrm{DAS} 28-\mathrm{CRP}$, mean $\pm S D$ & $3.5 \pm 0.7$ \\
\hline $\mathrm{ESR}(\mathrm{mm})$, mean $\pm \mathrm{SD}$ & $41.9 \pm 15.2$ \\
\hline $\mathrm{CRP}(\mathrm{mg} / \mathrm{dl})$, mean $\pm \mathrm{SD}$ & $8.1 \pm 3.2$ \\
\hline RF positivity, n (\%) & $74(54.8)$ \\
\hline RF high titer, n (\%) & $42(31.1)$ \\
\hline CCP positivity, $\mathrm{n}(\%)$ & $62(45.9)$ \\
\hline CCP high titer, n (\%) & $373(24.4)$ \\
\hline Double RF and CCP positivity, $\mathrm{n}$ (\%) & $61(45.2)$ \\
\hline \multicolumn{2}{|l|}{ DXA } \\
\hline \multicolumn{2}{|l|}{ LS } \\
\hline $\mathrm{BMD}\left(\mathrm{gm} / \mathrm{cm}^{2}\right)$, mean $\pm S D$ & $0.927 \pm 0.205$ \\
\hline T-score $<-1.0, \mathrm{n}(\%)$ & $22(16.2)$ \\
\hline \multicolumn{2}{|l|}{ FN } \\
\hline $\mathrm{BMD}\left(\mathrm{gm} / \mathrm{cm}^{2}\right)$, mean $\pm \mathrm{SD}$ & $0.782 \pm 0.183$ \\
\hline T-score $<-1.0, \mathrm{n}(\%)$ & $30(22.2)$ \\
\hline \multicolumn{2}{|l|}{ TH } \\
\hline $\mathrm{BMD}\left(\mathrm{gm} / \mathrm{cm}^{2}\right)$, mean $\pm \mathrm{SD}$ & $0.766 \pm 0.178$ \\
\hline T-score $<-1.0, \mathrm{n}(\%)$ & $32(23.7)$ \\
\hline \multicolumn{2}{|l|}{ Either LS, FN or TH } \\
\hline T-score $<-1.0, n(\%)$ & $40(29.6)$ \\
\hline
\end{tabular}

\section{Impact of ACPA positivity and levels on BMD}

Patients with decreased BMD were more prevalent ACPA-positive than patients with normal BMD ( $\triangleright$ Table 2). In addition, to explore the impact of the ACPA titer on the BMD, at the LS, FN and TH, we had stratified the patients into 3 subgroups according to ACPA status. The patients with high ACPA level had significantly lower BMD than patients with low ACPA level and also than patients who were negative for ACPA at all sites. Also, patients with low ACPA level had significantly lower BMD than patients who were negative for ACPA at all sites ( $>$ Fig. $2 a-c)$.

\section{Impact of RF positivity and levels on BMD}

Patients with decreased BMD were more prevalent RF-positive than patients with normal BMD ( $\triangleright$ Table 2 ). Our patients were also stratified according to the RF status to measure the impact of RF status on BMD. The patients with high RF level had significantly lower BMD than patients with low RF level and also than patients who were negative for RF at all sites. Also, patients with low RF level had significantly lower BMD than patients who were negative for RF at all sites ( $\mathbf{F i g} . \mathbf{2 d - f}$ ).
- Table 2 Comparison of the demographic and clinical characteristics between ERA patients with and without decreased BMD.

\begin{tabular}{|c|c|c|c|}
\hline & \multirow{2}{*}{$\begin{array}{l}\text { ERA patients } \\
\text { with decreased } \\
\text { BMD } \\
\text { Mean } \pm \text { SD }\end{array}$} & \multicolumn{2}{|l|}{$\begin{array}{l}\text { ERA patients } \\
\text { with normal } \\
\text { BMD }\end{array}$} \\
\hline & & Mean \pm SD & $\mathbf{p}$ \\
\hline Age (years) & $46.1 \pm 3.7$ & $46.4 \pm 3.5$ & 0.627 \\
\hline BMI $\left(\mathrm{kg} / \mathrm{m}^{2}\right)$ & $23.9 \pm 3.0$ & $24.6 \pm 2.9$ & 0.168 \\
\hline \multicolumn{4}{|l|}{ Vitamin D status, n (\%) } \\
\hline Normal & $23(31.9)$ & $17(27)$ & \\
\hline Insufficiency & $22(30.6)$ & $19(30.2)$ & \\
\hline Deficiency & $27(38.5)$ & 27 (42.9) & 0.770 \\
\hline $\begin{array}{l}\text { Duration of symptoms } \\
\text { (weeks) }\end{array}$ & $11.6 \pm 1.8$ & $11.4 \pm 1.7$ & 0.614 \\
\hline DAS28-ESR & $4.3 \pm 0.8$ & $4.1 \pm 0.7$ & 0.194 \\
\hline DAS28-CRP & $3.6 \pm 0.7$ & $3.5 \pm 0.6$ & 0.380 \\
\hline $\mathrm{ESR}(\mathrm{mm})$ & $42.8 \pm 15.5$ & $40.9 \pm 15.0$ & 0.464 \\
\hline CRP $(\mathrm{mg} / \mathrm{dl})$ & $8.4 \pm 3.2$ & $7.8 \pm 3.2$ & 0.290 \\
\hline RF-positive, n (\%) & $57(79.2)$ & $17(27)$ & $<0.001$ \\
\hline RF high titer, n (\%) & $35(48.6)$ & $7(11.1)$ & $<0.001$ \\
\hline CCP-positive, n (\%) & $32(44.4)$ & $11(17.5)$ & $<0.001$ \\
\hline CCP high titer, n (\%) & $28(38.9)$ & $9(14.3)$ & $<0.001$ \\
\hline $\begin{array}{l}\text { Double RF and CCP } \\
\text { positivity, } \mathrm{n}(\%)\end{array}$ & $27(37.5)$ & $6(9.5)$ & $<0.001$ \\
\hline
\end{tabular}

\section{Impact of Auto-antibodies on BMD after Adjustment for Confounding Factors}

To determine whether the relationship between BMD and patient stratification according to ACPA and RF status were attributed to the effect of the auto-antibodies or the result of bias related to subgroups' characteristic differences, we fitted a multivariable analysis model in which we included in the variables that are known to impact the BMD including age, BMI and vitamin D status and duration of the symptoms. As shown in > Table 3, after adjustment for these variables, patient stratification according to ACPA status and RF status (into negative, low-positive and high positive) still a significant independent variables associated with lower BMD values.

\section{Discussion}

The main findings of our study, is that reduced systemic BMD is prevalent in patients with early RA naïve to treatment, and classic osteoporosis related risk factors and disease related risk factors had negligible impact on BMD. However, ACPA-positivity and RF-positivity appear to be associated with significant reduction of the systemic BMD in the patents with early RA.

Our results had shown that $29.6 \%$ of the patients with early RA had evidence of low BMD. Consistent with our results, earlier reports showed evidence of low BMD in a small proportion of patients. In patients with untreated early RA, the reduced BMD were observed in $35.5 \%$ [21], $24.7 \%$ [22]. In an earlier study, Forslind 

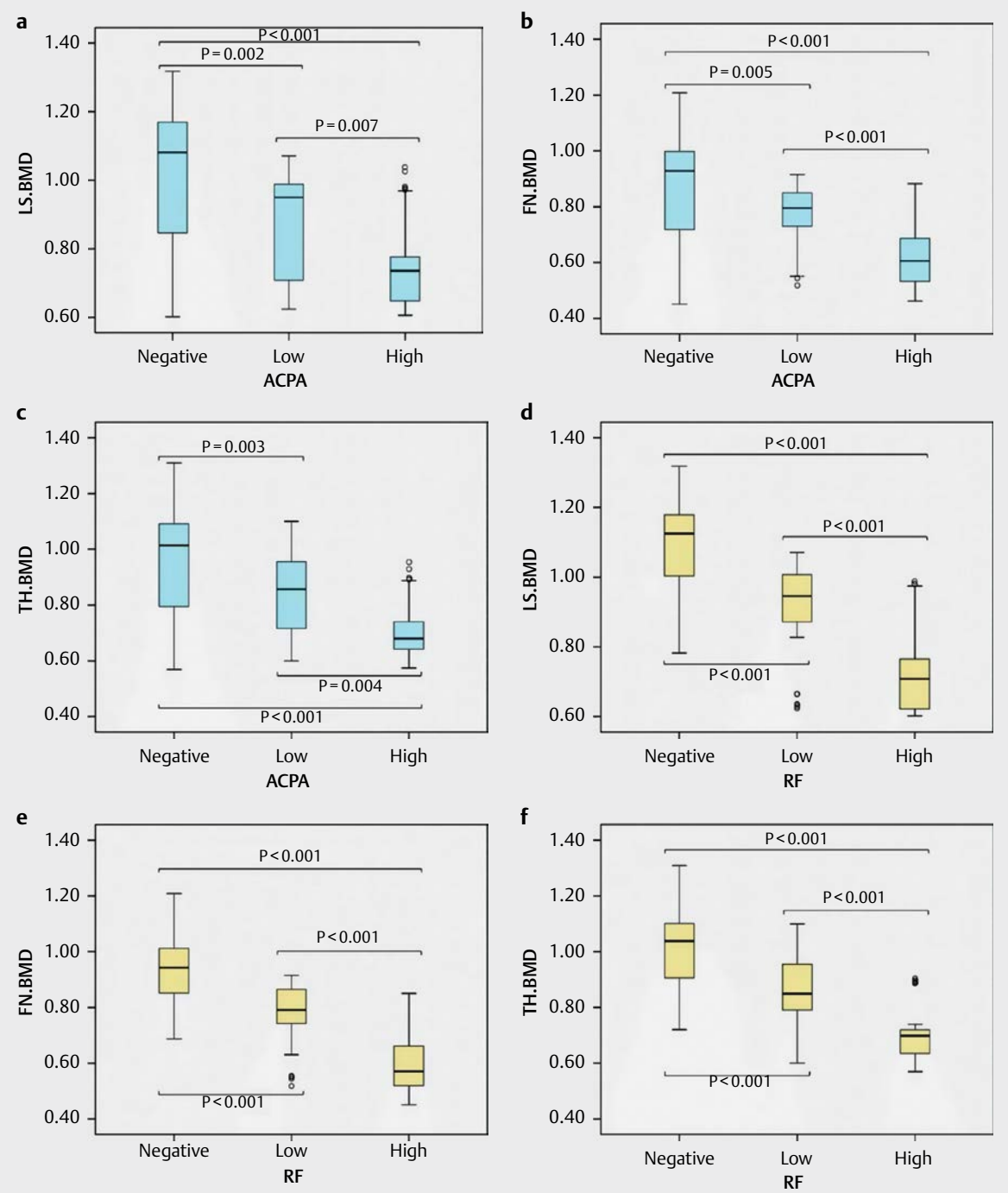

- Fig. 2 The association between the BMD $(\mathrm{g} / \mathrm{cm} 2)$ at the $L S, F N$ and TH in the subgroups of the ERA patients classified according to the ACPA titers (a, $\mathbf{b}$ and $\mathbf{c}$ respectively) and RF titers (d, e and $\mathbf{f}$ respectively). Data are presented as median and interquartile range. Dots represent the outliers. Statistical significance was estimated using the Mann-Whitney $U$ test.

et al. [23] reported reduced bone mass in $46 \%$ of the women with recent $\mathrm{RA}$. The age of the women in the study of Forslind et al. ranged from 55 to 61 years which may explain for the higher proportion of the reduced bone mass than in our study.

The inclusion of premenopausal females, the short duration of RA symptoms, all patients had an active disease and lack of treatment could exclude the association of traditional osteoporosis risk factors or the disease related factors to the reduced BMD in our patients with early RA in agreement with earlier studies [21] and in contrast to findings of other studies that enrolled patients with early RA but with longer disease duration or variable treatment [22-24].

The presence of reduced systemic BMD in early stages of the RA indicated that while synovial inflammation may take a long time to produce systemic effects such as significant generalized BMD changes [25], reduced BMD in early stages of RA appears to be coupled with autoimmunity. Relevant to this concept, our results had confirmed the recent evidence that link the ACPA and RF to reduced BMD in patients with early RA [21, 24].

The study of Bugatti et al. [21] had shown that high levels of RF would enhance the association between ACPA and reduced BMD. Sensitive imaging modalities showed that the size of bone erosions in RA patients was influenced by positive ACPA and higher RF levels [18], and also showed that pro-inflammatory cytokine production increased with combined presence of ACPA and RF [26, 27]. It had been suggested that the RF activity might enhance an inflammatory background sub clinically that could augment the ACPA-mediated activation of osteoclasts.

The results of this study support assumption that the presence of ACPA and RF may lead systemic osteoporosis through the activation of osteoclasts independent on the chronic inflammation. This concept is based on the following 3 major findings: (a) evidence of reduced systemic BMD in the early stages of RA; (b) The impact of the disease on BMD was not directly related to the disease activ- 
- Table 3 Association of ACPA and other variables on BMD at LS, FN and $\mathrm{TH}$.

\begin{tabular}{|l|r|r|r|}
\hline & $\begin{array}{l}\boldsymbol{\beta} \text { co- } \\
\text { efficient }\end{array}$ & $\mathbf{9 5 \% ~ C I}$ & $\mathbf{P}$ \\
\hline Dependent variable: LS.BMD & & & \\
\hline Age & 0.046 & $-0.004 ; 0.010$ & 0.461 \\
\hline BMI & 0.019 & $-0.007 ; 0.010$ & 0.755 \\
\hline Vitamin D & -0.042 & $-0.019 ; 0.010$ & 0.500 \\
\hline Duration of symptoms & -0.057 & $-0.044 ; 0.016$ & 0.360 \\
\hline RF status & -0.782 & $-0.231 ;-0.140$ & $<0.001$ \\
\hline ACPA status & -0.518 & $0.164 ;-0.090$ & $<0.001$ \\
\hline Dependent variable: FN.BMD & & & \\
\hline Age & 0.047 & $-0.004 ; 0.008$ & 0.442 \\
\hline BMI & 0.018 & $-0.006 ; 0.009$ & 0.768 \\
\hline Vitamin D & -0.023 & $-0.015 ; 0.010$ & 0.704 \\
\hline Duration of symptoms & -0.070 & $-0.042 ; 0.011$ & 0.252 \\
\hline RF status & -0.820 & $-0.212 ;-0.133$ & $<0.001$ \\
\hline ACPA status & -0.501 & $0.142 ;-0.076$ & $<0.001$ \\
\hline Dependent variable: FN.BMD & & & \\
\hline Age & 0.039 & $-0.004 ; 0.008$ & 0.442 \\
\hline BMI & 0.014 & $-0.007 ; 0.008$ & 0.768 \\
\hline Vitamin D & -0.030 & $-0.016 ; 0.010$ & 0.704 \\
\hline Duration of symptoms & -0.054 & $-0.039 ; 0.015$ & 0.252 \\
\hline RF status & -0.746 & $-0.196 ;-0.114$ & $<0.001$ \\
\hline ACPA status & -0.515 & $0.143 ;-0.078$ & $<0.001$ \\
\hline & & & \\
\hline
\end{tabular}

ity or disease duration and (c) the regression analysis had shown the significant association of ACPA and RF with the reduced systemic BMD after adjustment for possible confounding factors.

It is important, in this context, to recall the key role of vitamin-D on bone metabolism, as serum vitamin D was significantly lower in RA patients than that in controls [28]. Based on the finding that patients with positive ACPA might have higher prevalence of vitamin D insufficiency [29], it had been suggested that the association between auto-antibodies and reduced BMD is possibly mediated by low vitamin $\mathrm{D}$ levels. The results of the regression analysis had revealed that the effect of auto-antibodies on BMD is not associated with low vitamin D levels.

Our study had some limitations. We evaluated the association between the presence of ACPA and high levels of RF with systemic BMD, but not evaluated at the juxta-articular level, in early RA patients' naïve for treatment. Besides the impermanence of evaluating other bone quality parameters, including microarchitecture, mineralization and turnover that may better help to define the impact of auto-antibodies on bone loss.

\section{Conclusion}

In conclusion, our data suggest that patients with positive RF or ACPA have increased risk for development of reduced systemic BMD since the earliest RA stages. Furthermore, the risk for osteoporosis increases by presence of high levels of RF or ACPA. Measurement of BMD should be performed for ACPA- or RF-positive patients with early RA.

\section{Conflict of Interest}

The authors declare no conflict of interest.

\section{References}

[1] Deodhar AA, Woolf AD. Bone mass measurement and bone metabolism in rheumatoid arthritis: a review. $\mathrm{Br}$ ] Rheumatol 1996; 35 : 309-322

[2] Haugeberg G, Uhlig T, Falch JA et al. Bone mineral density and frequency of oteoporosis in female patients with rheumatoid arthritis: results from 394 patients in the Oslo County Rheumatoid Arthritis register. Arthritis Rheum 2000; 43: 522-530

[3] Sinigaglia L, Nervetti A, Mela Q et al. A multicenter cross sectional study on bone mineral density in rheumatoid arthritis. Italian Study Group on Bone Mass in Rheumatoid Arthritis. J Rheumatol 2000; 27 : 2582-2589

[4] Guler-Yuksel M, Bijsterbosch J, Goekoop-Ruiterman YP et al Bone mineral density in patients with recently diagnosed, active rheumatoid arthritis. Ann Rheum Dis 2007; 66: 1508-1512

[5] van Staa T, Geusens P, Bijlsma JW et al. Clinical assessment of the long-term risk of fracture in patients with rheumatoid arthritis. Arthritis Rheum 2006; 54: 3104-3112

[6] Roux C. Osteoporosis in inflammatory joint diseases. Osteoporos Int. 2011; 22: 421-433

[7] Michel BA, Bloch DA, Fries JF. Predictors of fractures in early rheumatoid arthritis. J Rheumatol 1991; 18: 804-808

[8] Schett G, Gravallese E. Bone erosion in rheumatoid arthritis: mechanisms, diagnosis and treatment. Nat Rev Rheumatol 2012; 8: 656-664

[9] Kocijan R, Harre U, Schett G. ACPA and bone loss in rheumatoid arthritis. Curr Rheumatol Rep 2013; 15: 366

[10] Walsh NC, Gravallese EM. Bone remodeling in rheumatic disease: a question of balance. Immunol Rev 2010; 233: 301-312

[11] Bugatti S, Manzo A, Caporali R et al. Assessment of synovitis to predict bone erosions in rheumatoid arthritis. Ther Adv Musculoskelet Dis 2012; 4: 235-244

[12] Harre U, Georgess D, Bang $\mathrm{H}$ et al. Induction of osteoclastogenesis and bone loss by human autoantibodies against citrullinated vimentin. J Clin Invest. 2012; 122: 1791-1802

[13] Krishnamurthy A, Joshua V, Haj Hensvold A et al. Identification of a novel chemokine-dependent molecular mechanism underlying rheumatoid arthritis-associated autoantibody-mediated bone loss. Ann Rheum Dis 2016; 75: 721-729

[14] van den Broek M, Dirven L, Klarenbeek NB et al. The association of treatment response and joint damage with ACPA-status in recent-onset RA: a subanalysis of the 8-year follow-up of the BeSt study. Ann Rheum Dis 2012; 71: 245-248

[15] Hensvold AH, Joshua V, Li W et al. Serum RANKL levels associate with anti-citrullinated protein antibodies in early untreated rheumatoid arthritis and are modulated following methotrexate. Arthritis Res Ther 2015; 17: 239

[16] Catrina Al, Joshua V, Klareskog L et al. Mechanisms involved in triggering rheumatoid arthritis. Immunol Rev 2016; 269: 162-174 
[17] Aletaha D, Neogi T, Silman AJ et al. 2010; rheumatoid arthritis classification criteria: an American College of Rheumatology/European League Against Rheumatism collaborative initiative. Ann Rheum Dis 2010; 69: 1580-1588

[18] Hecht C, Englbrecht M, Rech J et al. Additive effect of anti-citrullinated protein antibodies and rheumatoid factor on bone erosions in patients with RA. Ann Rheum Dis 2015; 74: 2151-2156

[19] Wells G, Becker JC, Teng J et al. Validation of the 28-joint Disease Activity Score (DAS28) and European League Against Rheumatism response criteria based on C-reactive protein against disease progression in patients with rheumatoid arthritis, and comparison with the DAS28 based on erythrocyte sedimentation rate. Ann Rheum Dis 2009; 68: 954-960

[20] Report of a WHO Study Group. Assessment of fracture risk and its application to screening for postmenopausal osteoporosis. World Health Organ Tech Rep Ser 1994; 843: 1-129

[21] Bugatti S, Bogliolo L, Vitolo B et al. Anti-citrullinated protein antibodies and high levels of rheumatoid factor are associated with systemic bone loss in patients with early untreated rheumatoid arthritis. Arthritis Res Ther 2016; 18: 226

[22] Güler-Yüksel M, Bijsterbosch J, Goekoop-Ruiterman YP et al. Bone mineral density in patients with recently diagnosed, active rheumatoid arthritis. Ann Rheum Dis 2007; 66: 1508-1512

[23] Forslind K, Keller C, Svensson B et al. Reduced bone mineral density in early rheumatoid arthritis is associated with radiological joint damage at baseline and after 2 years in women. J Rheumatol 2003; 30: 2590-2596
[24] Llorente I, Merino L, Ortiz AM et al. Anti-citrullinated protein antibodies are associated with decreased bone mineral density: baseline data from a register of early arthritis patients. Rheumatol Int 2017; 37: 799-806

[25] Güler-Yüksel M, Allaart CF, Goekoop-Ruiterman YP et al. Changes in hand and generalised bone mineral density in patients with recent-onset rheumatoid arthritis. Ann Rheum Dis 2009; 68: 330-336

[26] Sokolove J, Johnson DS, Lahey LJ et al. Rheumatoid factor as a potentiator of anti-citrullinated protein antibody mediated inflammation in rheumatoid arthritis. Arthritis Rheumatol 2014; 66: 813-821

[27] Laurent L, Anquetil F, Clavel C et al. IgM rheumatoid factor amplifies the inflammatory response of macrophages induced by the rheumatoid arthritis-specific immune complexes containing anticitrullinated protein antibodies. Ann Rheum Dis 2015; 74: 1425-1431

[28] Lin J, Liu J, Davies ML et al. Serum vitamin D level and rheumatoid arthritis disease activity: review and meta-analysis. PLoS One 2016; 11: e0146351

[29] Kerr GS, Sabahi I, Richards JS et al. Prevalence of vitamin D insufficiency/deficiency in rheumatoid arthritis and associations with disease severity and activity. J Rheumatol 2011; 38: 53-59 